Kajian Jurnalisme

ISSN 2549-0559 (cetak) ISSN 2549-1946 (online)

Volume 02 Nomor 02 Tahun 2019

\title{
Rebranding Majalah Konvensional Gogirl! Menjadi Media Hibrida Playzine Dan Perubahan Manajemen Redaksi
}

\author{
Fadhila Auliya Widiaputri dan Siti Karlinah \\ Program Studi Jurnalistik, Fakultas Ilmu Komunikasi Universitas Padjadjaran \\ E-mail: dhilawp@gmail.com
}

\begin{abstract}
This research aims to analyze the rebranding process of GoGirl! from a conventional magazine into a hybrid Playzine media and its implications for the editorial team. This research uses qualitative method with explanatory case study approached by Robert $K$. Yin. The research show that the strategy to create rebranding into a hybrid Playzine media is taken based on considerations of GoGirl! officials who are Anita Moran, Nina Moran, and Githa Moran, in seeing the life-style shifting of GoGirl! readers target. The rebranding process consists of four stages started with repositioning by changing its tagline and media form. The second stage is renaming its form into a Playzine. The third is redesigning its tangible and intangible elements. And the last stage of its rebranding process is relaunching the product through media social. GoGirl! rebranding has been implicating the management of its editorial team in some aspects such as content arrangement, editorial work-flow, and workload addition to its journalists.
\end{abstract}

Keywords: hybrid media, printed media, online media, playzine, rebranding

\begin{abstract}
Abstrak
Penelitian ini bertujuan mengkaji proses rebranding GoGirl! dari majalah konvensional menjadi media hibrida Playzine dan implikasinya pada pengelolaan ruang redaksi. Penelitian ini dilakukan dengan menggunakan menggunakan metode penelitian kualitatif studi kasus eksplanatoris Robert K. Yin. Hasil penelitian menunjukan bahwa kebijakan memilih strategi rebranding menjadi media hibrida Playzine berdasarkan pertimbangan para petinggi GoGirl! yakni Anita Moran, Nina Moran, dan Githa Moran dalam melihat perubahan gaya hidup target khalayak GoGirl!. Proses rebranding terdiri dari empat tahap dimulai dari repositioning melalui perubahan tagline dan bentuk media. Tahap kedua, renaming menjadi Playzine. Tahap ketiga, redesign elemen tangible dan intangible. Tahap terakhir proses rebranding adalah relaunching menggunakan akun media sosial. Rebranding GoGirl! berimplikasi pada pengelolaan ruang redaksi pada aspek penentuan konten, perubahan alur kerja, dan penambahan beban kerja wartawan.
\end{abstract}

Kata-kata Kunci: media hibrida, media cetak, playzine, rebranding

\section{Pendahuluan}

Kehidupan selalu ditandai dengan perubahan. Begitu pula dalam kehidupan media massa. Seiring masa perkembangannya, media massa berubah menjadi sebuah bisnis. Dimana idealisme media massa sebagai penyampai informasi harus pula didukung dengan strategi industri. Seperti yang dikemukakan oleh Totok Djuroto dalam buku Manajemen Penerbitan Pers.

http://jurnal.unpad.ac.id/kajian-jurnalisme 
226 | Kajian Jurnalisme

ISSN 2549-0559 (cetak) ISSN 2549-1946 (online)

Volume 02 Nomor 02 Tahun 2019

"Pengusaha media massa (dibaca: pers) kini harus banting stir, tidak lagi mengandalkan idealisme dalam mengelola perusahaannya tetapi juga meningkatkannya secara industri. Itu sebabnya, akhir abad ke 20, dunia pers nasional kita mengenal sebutan industrialisasi pers. Maksudnya, pers yang dikelola secara industri dengan perhitungan profit oriented." (Djuroto, 2004)

Adanya perubahan media massa dari sarana penyampai informasi menjadi bisnis, menuntut media massa untuk saling bersaing. Terutama bagi media cetak. Tidak hanya harus bersaing dengan sesama media cetak atau media elektronik. Saat ini media massa cetak juga dihadapkan pada persaingan dengan media online yang selalu disebut-sebut sebagai ancaman kematian bagi media cetak. Karena media online menawarkan kelebihan yang tidak dimiliki media massa cetak, seperti kemudahan akses, kecepatan, dan jumlah data yang tidak terbatas.

Meskipun begitu, para ahli optimis bahwa media cetak tidak akan mati asal mau berkompetisi untuk "memutar otak" mengubah strategi ataupun menciptakan produk media baru yang berkualitas dan sesuai dengan kebutuhan pasar. Seperti yang dikemukakan oleh Charles Darwin (dalam Kasali, 2005: 17) bahwa saat ini bukan yang terkuat yang dapat bertahan melainkan yang paling adaptif dengan perubahan. Untuk itu, media massa cetak membutuhkan strategi baru.

Pembicaraan tentang strategi tidak akan terlepas dari pembicaraan manajemen. Dimana manajemen membutuhkan strategi sebagai motor penggerak. Dalam ilmu manajemen, terdapat istilah manajemen strategi yang berarti suatu proses pengambilan keputusan dan tindakan untuk pengembangan strategi efektif dalam membantu perusahaan mencapai tujuannya (Taufiqrokhman, 2016:16). Lebih lanjut Pearce dan Robinson (1997:20) mendefinisikan manajemen strategi sebagai sekumpulan keputusan dan tindakan yang menghasilkan perumusan (formulasi) dan pelaksanaan (implementasi) rencana-rencana yang dirancang untuk mencapai sasaran-sasaran perusahaan.

Fandy Tjiptono (2008: 373) menyatakan bahwa salah satu strategi manajemen perusahaan agar dapat tetap bertahan saat ini ialah dengan melakukan perubahan atau dalam hal ini dimaksud rebranding. Mendiola B Wirayawan dalam Kamus Brand (2008), bahwa rebranding adalah kegiatan terintegrasi dan terencana untuk mengubah posisi sebuah brand secara internal maupun eskternal, supaya brand terlihat lebih baru dan memiliki nilai tambah yang baru pada brand itu sendiri.

Alasan yang mendasari perusahaan untuk melakukan aktivitas rebranding baik secara keseluruhan ataupun tidak dapat disebabkan oleh beberapa hal, antara lain yaitu untuk meningkatkan awareness masyarakat, memodifikasi citra perusahaan atau brand tersebut, adanya perubahaan struktur organisasi, perubahan strategi perusahaan, atau munculnya faktorfaktor dari lingkungan eksternal yang menuntut perusahaan untuk melakukan aksi perubahan (dalam Muzellec, dkk. 2004:33-34).

Sebuah brand memiliki beberapa elemen pembeda dari brand lainnya. Elemen-elemen tersebut disebut elemen tangible atau elemen yang terlihat dan elemen intangible atau elemen yang tidak terlihat (Tjiptono, 2008:347). Secara kasat mata, ciri utama rebranding dapat dilihat melalui perubahan elemen tangible seperti nama, logo, desain grafis, warna, dan lain 
sebagainya. Namun dalam penerapannya, rebranding juga dapat membuat perubahan pada elemen intangible seperti nilai, citra, budaya kerja dan lain sebagainya.

Salah satu media massa di Indonesia yang melakukan rebranding adalah GoGirl!. Redaksi GoGirl! pertama kali beroperasi pada tanggal 29 November 2004 dan terbit pertama kali pada Februari 2005. Saat pertama kali terbit, GoGirl! mengusung konsep "Magazine For Real". Dimana GoGirl! ingin menjadi majalah yang dekat dan sesuai dengan kehidupan remaja perempuan di zaman itu. Oleh karena itu, dalam setiap edisinya GoGirl! menampilkan sejumlah konten tetap seperti kecantikan, fashion, kesehatan, gaya hidup, realita, gosip, dan psikologi yang realistis dengan kehidupan sehari-hari remaja perempuan berusia 15-25 tahun yang sesuai dengan target pembacanya.

Bercita-cita untuk selalu menjadi yang lebih baik, pada Oktober 2016, GoGirl! melakukan rebranding. Secara kasat mata, perubahan dalam rebranding GoGirl! ini dapat terlihat pada elemen tangible yang ada pada majalah mereka. Seperti pada tampilan sampul majalah. Jika sebelumnya sampul GoGirl! selalu konsisten menggunakan foto artis wanita luar negeri. Namun setelah rebranding, ketentuan sampul GoGirl! menjadi lebih fleksibel. Tidak ada ketentuan khusus harus menggunakan foto artis wanita luar negeri seperti tampilan sampul GoGirl! sebelumnya. (History GoGirl! http://www.gogirlmagz.com)

Perubahan lain dalam rebranding GoGirl! juga terlihat pada penyajian konten dalam majalahnya. Dimana setelah rebranding, GoGirl! kerap mengintegrasikan sajian konten dalam majalahnya dengan portal online-nya seperti web, youtube, dan sejumlah media sosial (twitter, facebook, dan instagram) mereka.

Tidak hanya pada elemen tangible. Rebranding GoGirl! juga mempengaruhi adanya perubahan pada elemen intangible-nya. GoGirl! tidak lagi memperkenalkan diri sebagai sebuah media konvensional majalah atau magazine melainkan sebuah media hybrid bernama Playzine. Hal ini disampaikan melalui akun instagram resmi mereka dalam @gogirlmagz pada tanggal 3 Oktober 2016:

It's Finnaly Here! This is not just a magazine. It's a hybrid! A Source of inspirations, play tool, and activity platform. Inside there are pages that's meant to be written over, cut and pasted on, photographed, and shared. In each page, we ask you, playa (not reader anymore) to showcase what you do with it and post it on ig with \#ggplay. It is not a magazine. It's a play space! It's a Playzine! Enjoy!

Menurut Kamus Besar Bahasa Indonesia (KBBI), hybrid atau hibrida adalah suatu turunan yang dihasilkan dari perkawinan antara dua jenis yang berlainan. Leuuwis (2013) mengartikan media hibrida muncul dari kombinasi potensi yang ditawarkan oleh media massa konvensional dan komunikasi interpersonal. Lebih jauh, Leeuwis mengartikan media hibrida sebagai media berbasis teknologi yang mengkombinasikan kekayaan fungsional antara media massa dan komunikasi interpersonal sehingga dapat menjangkau interaktivitas dalam ruang dan waktu yang lebih tinggi dibanding media konvensional. Begitu pula yang dilakukan oleh majalah GoGirl!.

Menurut pengamatan peneliti, konten GoGirl! setelah rebranding merupakan kombinasi antara potensi informatif yang ada dalam media massa konvensional dan potensi interaktif yang ada dalam komunikasi interpersonal. Dimana GoGirl! tidak hanya menyajikan sejumlah 
228 | Kajian Jurnalisme

ISSN 2549-0559 (cetak) ISSN 2549-1946 (online)

Volume 02 Nomor 02 Tahun 2019

konten artikel dan konten iklan layaknya majalah pada umumnya tetapi juga menyajikan sejumlah konten kreatif yang dapat diisi, dimainkan, dan dikreasikan oleh para pembacanya. Seperti namanya Playzine yang merupakan gabungan dari kata play yang berarti bermain dan zine dari kata magazine yang berarti majalah. GoGirl! mengubah konsep menjadi seinteraktif mungkin untuk mengajak pembacanya tidak hanya sekedar membaca tetapi juga bermain.

Dengan perubahan konsep tersebut, peneliti melihat adanya implikasi pada manajemen redaksi GoGirl!. Mengingat manajemen redaksi merupakan sebagai salah satu dari tiga bidang kegiatan penerbitan pers (Djuroto. 2004:15). Lebih lanjut George R. Terry dan L.W. Rue (2003) menjelaskan bahwa manajemen redaksi merupakan penerapan teori fungsi manajemen menurut, yaitu perencanaan, pengorganisasian, penggerakan, dan pengawasan. Oleh karena itu, peneliti ingin mengetahui bagaimana kebijakan-kebijakan terkait perencanaan, pengorganisasian, penggerakan, dan pengawasan yang diterapkan manajemen redaksi GoGirl! setelah melakukan rebranding menjadi media hibrida Playzine.

Rebranding GoGirl! ini menarik minat peneliti mengingat penelitian perubahan media konvensional menjadi media hibrida di Indonesia masih jarang dilakukan. Oleh karena itu, peneliti berharap penelitian ini bisa menjadi salah satu bahan referensi untuk media massa cetak dalam menghadapi persaingan dengan media online tanpa harus menghilangkan bentuk fisik majalahnya. Terutama untuk media massa cetak seperti GoGirl! dengan target pembaca berusia 15-25. Dimana pada rentang umur tersebut, pola bermedianya lebih dekat dengan konten media online.

Seorang kolumnis online Barron, Howard Gold menjelaskan bahwa model bisnis percetakan sedang meledak ketika pembaca yang lebih muda berpaling kepada media elektronik (internet) untuk mendapatkan berita (Baran, Stanley J. 2011). Hal ini sesuai dengan hasil riset Asosiasi Penyelenggara Jasa Internet Indonesia (APJII) yang menyatakan bahwa dari total populasi penduduk Indonesia yang berjumlah 256,2 juta. Tercatat sebanyak 132,7 juta penduduk Indonesia merupakan pengguna internet. Dimana pengguna terbanyak berusia 25 - 34 tahun dan 10 - 24 tahun, dengan presentase berturut-turu 35,8 \% atau 47,5 juta dan $26,9 \%$ atau 35,6 juta.

Perubahan pola bermedia pembaca muda juga pernah dibahas oleh Supadiyanto dalam buku Implikasi Teknologi Digital dan Internet (2013). Dalam buku tersebut, Supadiyanto menyebutkan ada empat ancaman yang menimpa media massa cetak di era digital diantaranya yaitu: (1) hadirnya media online dapat secara langsung maupun tidak langsung membuat pembaca media cetak beralih ke media online yang menimbulkan penurunan jumlah pembaca media cetak, (2) perubahan perilaku anak muda jaman sekarang yang lebih memilih teknologi digital dibanding konvensional, (3) migrasi pengiklan media cetak ke media online. Meningkatnya kesadaran masyarakat akan kelestarian lingkungan hidup yang mengundang gerakan untuk tidak memakai, membeli, maupun membaca segala produk yang berasal dari kertas, termasuk media cetak.

Melihat fenomena tersebut, penerbitan media cetak harus tetap berusaha dan memiliki semangat juang yang tinggi. Dalam mengidentifikasi kemajuan teknologi era globalisasi, Totok Djuroto (2004:95) mengatakan intinya adalah mendekatkan jarak antara pelanggan dan 
penerbit. Perusahaan penerbitan media cetak harus sadar adanya implikasi dari kemajuan teknologi komunikasi dan informasi sehingga perbitan media cetak harus secara sungguhsungguh memenuhi selera pelanggan melalui bentuk dan cara kerja yang inovatif.

Ada dua aspek utama yang akan diteliti peneliti dalam penelitian ini. Aspek pertama yaitu tentang bagaimana proses rebranding media konvensional majalah GoGirl! menjadi media hibrida Playzine. Untuk menjelaskan aspek pertama tersebut peneliti akan menggunakan model proses rebranding dari Laurent Muzzelec. Dimana dalam model ini, Laurent membagi proses rebranding ke dalam empat tahapan yang penting dilakukan, yaitu: (1) reposisioning, (2) renaming, (3) redesign, (4) relaunching.

Adapun aspek yang kedua yaitu tentang bagaimana pengelolaan manajemen redaksi majalah GoGirl! setelah melakukan rebranding menjadi media hibrida Playzine dalam menghasilkan konten. Mengingat dalam rebranding ini majalah GoGirl! memperkenalkan sebuah "bentuk" media massa baru dengan sebutan media hibrida Playzine.

Untuk membahas aspek kedua tentang bagaimana kebijakan manajemen redaksi majalah GoGirl! setelah melakukan rebranding menjadi media hibrida Playzine dalam menghasilkan konten. Peneliti akan menggunakan teori fungsi manajemen dari George R. Terry dan L.W. Rue yang terkenal dengan istilah POAC atau Planning (Perencanaan), Organizing (Pengorganisasian), Actuating (Penggerakan), dan Controling (Pengawasan).

\section{Metode}

Dalam penelitian ini, peneliti akan menggunakan metode penelitian kualitatif. Jhon W. Creswell dalam karyanya yang berjudul Qualitative Inquiry and Research Design: Choosing Among Five Traditiongs (1998) mendefinisikan bahwa penelitian kualitatif sebagai proses penelitian yang mengeskpolrasi sebuah permasalahan sosial atau manusia. Dalam penelitian ini, peneliti membangun sebuah gambaran yang kompleks dan holistik, menganalisa kata-kata, melaporkan detil pandangan informan, dan mengolahnya dalam keadaan alamiahnya.

Sementara pendekatan yang digunakan peneliti ialah pendekatan studi kasus. Studi kasus berasal dari ilmu sosial dan humaniora yang digunakan dalam berbagai area, salah satunya yaitu penelitian yang bersifat evaluatif. Robert K. Yin dalam bukunya berjudul Studi Kasus: Desain dan Metode (2013) menjelaskan bahwa studi kasus adalah sebuah metode penelitian yang secara khusus menyelidiki fenomena kontemporer yang terdapat dalam konteks kehidupan nyata yang dilaksanakan ketika batasan-batasan antara fenomena dan konteksnya belum jelas, dengan menggunakan berbagai sumber data.

Salah satu kekhususan penelitian studi kasus sebagai metode penelitian terletak pada sifat objek yang diteliti. Menurut Yin, kasus di dalam penelitian studi kasus bersifat kontemporer, yaitu yang sedang berlangsung atau tengah berlangsung tetapi masih menyisakan dampak dan pengaruh luas yang masih dirasakan pada saat penelitian dilakukan tujuannya.

Selain itu, penelitian studi kasus sangat tepat digunakan pada penelitian yang bertujuan untuk menjawab pertanyaan bagaimana dan mengapa terhadap sesuatu yang diteliti (Yin, 2013). Melalui pertanyaan peneliti yang demikian, substansi mendasar yang terkandung dalam kasus yang diteliti dapat digali dengan mendalam. Sejalan dengan penjelasan Fandy Tjiptono (2008: 
Volume 02 Nomor 02 Tahun 2019

373), bahwa untuk membahas perubahan (dalam hal ini perubahan merek) harus benar-benar dilandasi oleh justifikasi yang kuat. Terutama menyangkut pertanyaan mengapa dan bagaimana.

Yin membagi studi kasus menjadi tiga jenis, yaitu:

1. Studi kasus deskriptif, yaitu studi kasus yang bersifat melacak urutan suatu peristiwa, menggambarkan sub budaya, dan menemukan fenomena kunci.

2. Studi kasus eksplanatoris, yaitu studi kasus dengan pertanyaan-pertanyaan "bagaimana" dan "mengapa". Menurut Yin (2013: 9), pertanyaan-pertanyaan "bagaimana" dan "mengapa" pada dasarnya lebih eksplanatoris dan lebih mengarah ke strategi-strategi studi kasus, historis, dan eksperimen.

3. Studi kasus eksploratoris, yaitu studi kasus yang berangkat dari beberapa rasional dan petunjuk, meskipun bisa jadi asumsi awalnya ternyata tidak terbukti. Tingkat rasional dan petunjuk yang sama ini juga harus mendasari studi kasus eksploratoris.

Berdasarkan pembagian studi kasus tersebut, peneliti menggunakan studi kasus eksplanatoris untuk mengetahui bagaimana proses rebranding GoGirl! dari majalah konvensional menjadi media hibrida Playzine dan implikasinya pada pengelolaan ruang redaksi. Dengan teknik pengumpulan data melalui wawancara, observasi, dokumentasi, dan perangkat fisik.

\section{Hasil dan Pembahasan}

Tidak dapat dipungkiri, kehadiran media online ditengah-tengah bisnis media memukul media cetak. Hal ini sampaikan oleh Anita Moran saat menjelaskan salah satu alasan rebranding GoGirl! pada bulan Oktober 2016. Alih-alih menghentikan produksi cetak seperti majalah remaja lainnya, Anita Moran bersama kedua saudaranya Nina Moran dan Githa Moran selaku pendiri GoGirl! memilih untuk mengubah strategi GoGirl! melalui rebranding.

"Memang benar, media online saat ini sangat memukul media cetak dan aku mengerti kenapa banyak majalah di luar sana yang memilih untuk menghentikan produksi cetaknya. Karena jujur untuk mempertahankan media cetak saat ini itu butuh tekat yang kuat banget. Kadang sudah tidak ada alasan lagi untuk mempertahankan media cetak seperti ini. Namun GoGirl! memiliki passion di bentuk buku. Jadi aku ingin tetap menjaga GoGirl! ada secara fisik. Gak masalah ketika nanti suatu saat GoGirl! hanya di-print sebanyak 1000 eksemplar sebulan. Aku gak ingin ada tidaknya GoGirl! hanya karena didikte oleh tuntutan eksemplar." (Anita Moran, Wawancara, 14 Juni 2017)

Anita Moran mengatakan dalam kurun waktu tiga tahun ke belakang GoGirl! mengalami hal yang sulit. Jumlah oplah GoGirl! yang awalnya mencapai 130.000 eksemplar saat ini turun menjadi 50.000 eksemplar. Penurunan jumlah eksemplar ini dinilai Anita Moran sebagai salah satu akibat dari adanya perubahan pola bermedia pembacanya. Dimana target pembaca GoGirl! yang berusia 15-25 tahun, saat ini dikenal sebagai generasi millenial atau digital native. Oleh karena itu, GoGirl! merasa perlu melakukan perubahan dengan menambahkan nilai baru pada majalah GoGirl!.

Robert G. Picard dalam jurnal berjudul Journalism, Value Creation and the Future of News Organizations mengatakan, ada tiga strategi penciptaan nilai: memberikan kinerja yang setara dengan pesaing tetapi menawarkan harga yang lebih rendah, menciptakan nilai tambah 
ISSN 2549-0559 (cetak) ISSN 2549-1946 (online)

Volume 02 Nomor 01 Tahun 2019

dengan menawarkan fitur yang berbeda yang tidak dimiliki pesaing, dan memberikan nilai lebih besar kepada konsumen daripada pesaing lainnya.

Adapun yang dilakukan oleh GoGirl! adalah poin kedua, yakni menciptakan nilai tambah dengan menawarkan fitur yang tidak dimiliki oleh media massa cetak lainnya. GoGirl! rebranding menjadi media hibrida Playzine. Dimana GoGirl! mengubah konsep menjadi seinteraktif mungkin untuk mengajak pembacanya tidak hanya sekedar membaca tetapi juga bermain.

"Kita ingin membuat sesuatu yang lebih fresh, yang lebih baru, dan yang pasti lebih relevan dengan dunia media saat ini. Oleh karena itu kita ingin beranjak dari konsep GoGirl! yang lama dan menciptakan konsep yang baru bernama Playzine ini. Di konsep Playzine ini kita ingin membuat sesuatu yang tidak akan ditemui orang di web maupun media sosial manapun. Apa yang tidak bisa orang dapetin? Nah yaitu activity, coloring, dan lain-lain pokoknya sesuatu yang membutuhkan aktivitas seperti doing something with the paper gitu." (Anita Moran, Wawancara, 14 Juni 2017)

Keputusan rebranding GoGirl! merupakan hasil dari rapat berkelanjutan tim GoGirl! yang berlangsung sejak bulan Mei - Oktober 2016. Dimana dalam rapat tersebut memuat empat tahap proses rebranding yang dikemukakan oleh Laurenz Muzzelec, dkk dalam artikel ilmiah berjudul Corporate Rebranding an Axploraotry Review (2004:34-35). Adapun lebih lanjut, keempat tahap proses itu ialah repositioning, renaming, redesign, dan relaunching.

a. Tahap Repositioning

Muzzelec (2004:34) menjelaskan bahwa tahap repositioning adalah tahap penetapan tujuan sebuah keputusan diambil untuk membuat posisi baru bagi perusahaan di benak para pelanggan, pesaing, dan pemangku kepetingan lainnya. Tahap repositioning ini merupakan tahap yang dinamis dan disesuaikan secara reguler dari waktu ke waktu untuk tetap selaras dengan tren pasar yang senantiasa bergerak.

Dalam kaitannya dengan penelitian ini strategi pertama yang dilakukan oleh GoGirl! yaitu dengan perubahan penggunaan tagline dari "Magazine For Real" menjadi "Insprired To Be Impacful'. Perubahan tagline ini didasari dari pandangan GoGirl! yang melihat bahwa tagline "Magazine For Real" sudah tidak relevan lagi dengan pola bermedia pembacanya saat ini. Khususnya untuk target pembaca GoGirl! yang berusia antara 15-25 tahun. Dimana saat ini, rentang waktu umur tersebut dikenal sebagai generasi millenial atau digital native.

William Strauss dan Neil Howe (2000) dalam artikel berjudul "Teaching and Reaching the Millennial Generation Through Media Literacy" yang dibuat oleh David Considine, Julie Horton, dan Gary Moorman yang menyebutkan bahwa generasi millenial adalah setiap anak yang tumbuh dewasa sejak kemunculan World Wide Web (WWW) dan bermacam-macam teknologi digital seperti telepon pintar, pesan teks, video game, dan pesan instan atau sebuah sistem pengiriman pesan cepat dengan menggunakan jejaring internet. Generasi millenial adalah manusia yang dilahirkan antara tahun 1982 - 2004. Lebih lanjut, dalam artikel tersebut disebutkan bahwa generasi millenial memiliki kemampuan lebih banyak dari pada generasi sebelumnya untuk mengakses lebih banyak informasi karena kemampuan mereka dalam menggunakan Information Communication Technology (ITC). Mereka dengan mudah menyesuaikan diri dengan teknologi terbarukan dan handal dalam menggunakan ICT secara kreatif dan inovatif (Considine, Horton, \& Moorman, 2009:472-472). 
Tidak hanya melalui tagline, strategi lain yang dilakukan GoGirl! yaitu dengan memperkenalkan bentuk baru medianya sebagai media hibrida Playzine. Hal tersebut disampaikan GoGirl! melalui akun akun instagram resmi mereka @gogirlmagz, pada bulan Oktober 2016.

Cees Leeuwis (2013:304) mengatakan bahwa media hibrida muncul dari kombinasi potensi yang ditawarkan oleh media massa konvensional dan komunikasi interpersonal. Lebih jauh, Leeuwis mengartikan media hibrida sebagai media berbasis teknologi yang mengkombinasikan kekayaan fungsional antara media massa dan komunikasi interpersonal sehingga dapat menjangkau interaktivitas dalam ruang dan waktu yang lebih tinggi dibanding media konvensional.

Penjelasan Leeuwis tersebut menggambarkan konsep media hibrida yang diusung GoGirl! saat ini. Dimana GoGirl! mengkombinasikan potensi informatif yang ada dalam media massa konvensional dan potensi interaktivitas yang ada dalam komunikasi interpersonal ke dalam konten-konten di majalahnya.

Meskipun begitu, GoGirl! memiliki pengertian media hibrida sendiri. Berdasarkan hasil penelitian peneliti, ada dua pengertian hibrida yang dimaksud GoGirl!. Pengertian pertama yaitu pengertian media hibrida yang disampaikan oleh Anita Moran sebagai media gabungan antara magazine dan activity book. Dimana pengertian ini menjelaskan isi konten GoGirl! saat ini yang tidak hanya menyajikan sejumlah konten artikel dan konten iklan layaknya majalah pada umumnya tetapi juga menyajikan sejumlah konten kreatif. Adapun pengertian hibrida kedua yaitu pengertian hibrida yang disampaikan oleh Syarifah Sahnath. Dimana pengertian media hibirda yang dimaksud GoGirl! merupakan gabungan dari beberapa keunggulan platform media yang berbeda seperti media cetak dan media online.

Dalam penelitian ini peneliti akan mengartikan media hibrida yang dimaksud GoGirl! sesuai dengan pengertian yang diucapkan oleh Anita Moran. Adapun keputusan ini berlandaskan dari hasil observasi virtual peneliti yang melihat jika pengertian media hibrida yang dimaksud GoGirl! lebih sesuai dengan pengertian media hibrida yang diartikan oleh Anita Moran. Dimana GoGirl! saat ini merupakan gabungan antara magazine dan activity book.

\section{b. Tahap Renaming}

Nama adalah indikator inti dalam sebuah brand. Dimana nama brand menjadi tempat kesadaran dan komunikasi perusahaan kepada para pelanggan, pesaing, dan pemangku kepentingan lainnya. Kapferer (dalam Muzzelec, dkk. 2004:34) menyiratkan bahwa sebuah nama mendefinisikan dan mewakili identitas produk dan citra perusahaan.

Mengingat pentingnya nama pada sebuah brand. Lebih lanjut Kapferer menjelaskan bahwa renaming atau mengubah nama, menjadi tahapan dimana nama menjadi media mengirimkan sinyal kuat kepada seluruh stakeholder bahwa perusahaan atau brand melakukan strategi, perubahan fokus, atau perubahan struktur pemilikan (dalam Muzzelec, dkk. 2004:34).

Sejak awal kehadirannya di tengah-tengah industri media cetak pada tahun 2005 hingga rebranding tahun 2017, GoGirl! tidak mengubah nama brand-nya. Namun melalui akun instagram resmi mereka @gogirlmagz, pada 3 Oktober 2016 GoGirl! tidak lagi memperkenalkan diri sebagai sebuah majalah atau magazine melainkan sebuah media hibrida bernama Playzine. 
ISSN 2549-0559 (cetak) ISSN 2549-1946 (online)

Volume 02 Nomor 01 Tahun 2019

Mengingat pentingnya peran nama dalam sebuah brand, pemilihan nama bukanlah suatu perkarang yang gampang. Untuk itu, dalam sebuah buku berjudul Strategi Pemasaran: Edisi Ketiga, Fandy Tjiptono (2008:347-348) menyebutkan bahwa nama brand dapat didasarkan pada sejumlah aspek, diantaranya yaitu descriptive names atau nama yang menggambarkan manfaat atau aspek kunci produk. Hal ini sejalan dengan penggunaan nama Playzine yang digunakan GoGirl!. Dimana Playzine menggambarkan keinginan GoGirl! untuk menyajikan sejumlah konten kreatif yang tidak hanya membuat pembaca sekedar membaca tetapi juga bermain atau beraktivitas.

Lebih lanjut Hadi Irawan (2004:47) dalam buku yang berjudul Smarter Marketing Moves, mengemukakan lima pedoman dalam pemilihan nama suatu brand. Adapun ke-lima pedoman itu antara lain, nama brand hendaknya mudah diingat, nama brand seharusnya mempertimbangkan asosiasi atau relevansi terhadap kategori produk dari brand tersebut, nama brand memiliki keunikan atau relatif berbeda dengan nama brand sejenis, nama brand yang konsisten dengan positioning, dan nama brand yang tidak bermakna negatif dalam bahasa lain. Merujuk pada pedoman tersebut, menurut peneliti nama Playzine telah memenuhi ke-lima pedoman tersebut.

Pertama, nama brand hendaknya mudah diingat. Nama Playzine mudah diingat karena hanya terdiri dari dua suku kata dan kata yang cukup sering digunakan dalam kehidupan seharihari.

Kedua, nama brand seharusnya mempertimbangkan asosiasi atau relevansi terhadap kategori produk dari brand tersebut. Nama Playzine mengandung kata zine dari magazine yang cukup menggambarkan kategori GoGirl! sebagai sebuah majalah.

Ketiga, nama brand memiliki keunikan atau relatif berbeda dengan nama brand sejenis. Dari hasil observasi peneliti, belum ada media cetak di Indonesia yang menggunakan nama serupa dengan Playzine.

Keempat, nama brand yang konsisten dengan positioning. Nama Playzine sangat menggambarkan posisi GoGirl! sebagai media hibrida yang merupakan gabungan dari magazine dan activity book. Dimana GoGirl! tidak hanya menyajikan sejumlah konten artikel dan konten iklan layaknya majalah pada umumnya tetapi juga menyajikan sejumlah konten kreatif.

Dan, kelima, nama brand yang tidak bermakna negatif dalam bahasa lain. Nama Playzine merupakan gabungan dari kata play dari bahasa Inggris yang berarti bermain dan zine dari magazine yang berarti majalah. Tidak ada makna negatif dari kedua kata tersebut.

c. Tahap Redesign

Tahapan dalam proses rebranding GoGirl! selanjutnya adalah tahap redesign. Pada tahap ini Muzzelec (2004:35) memfokuskan pada perubahan estetika brand dan elemen tangingble-nya, seperti logo, desain grafis, warna, dan lain sebagainya. Perubahan elemen tersebut memiliki peranan penting dalam membangun ekuitas brand terutama pada bagian tingkat kesadaran (brand awarness) dalam melahirkan posisi brand yang baru.

Untuk memulai penjelasan redesign pada elemen tangible, peneliti akan memulainya dari tampilan sampul GoGirl!. Sampul diibaratkan Ardianto (2014:122) sebagai pakaian dan 
aksesoris pada manusia. Menarik tidaknya sampul suatu majalah sangat bergantung pada tipe majalahnya, serta konsistensi atau keajegan majalah tersebut dalam menampilkan ciri khasnya.

Lebih lanjut Ardianto menambahkan bahwa pada umumnya sampul majalah wanita lebih mengutamakan nilai artistik dan keindahan serta kecantikan wajah dan tubuh model wanita (2014:123). Pernyataan Ardianto tersebut sejalan dengan konsep sampul GoGirl! sebelum rebranding. Dimana majalah GoGirl! selalu konsisten menggunakan foto artis wanita luar negeri pada sampulnya. Namun setelah rebranding ketentuan sampul majalah GoGirl! menjadi jauh lebih fleksibel. Anita Moran menjelaskan tidak ada ketentuan khusus harus menggunakan foto artis wanita luar negeri seperti tampilan sampul GoGirl! sebelumnya.

Lalu logo. Logo merupakan sebuah simbol yang dirancang untuk mewakili karakter dan menjadi identitas dari sebuah perusahaan. Biasanya perubahan logo menjadi pertanda awal adanya perubahan dalam sebuah perusahaan. Namun, dalam tahap redesign GoGirl! tidak mengubah logo brand-nya. Hanya saja, dalam tampilan sampul majalah GoGirl! yang baru penggunaan logo GoGirl! terlihat lebih kecil dari tampilan sampul sebelumnya.

Anita Moran mengatakan bahwa selama proses rebranding, pemilihan tampilan sampul yang paling susah ditetapkan. Untuk menentukan tampilan sampul yang baru, GoGirl! sempat mengadakan Forum Group Discussion (FGD) bersama 10 anak dari berbagai SMA dan SMP di jakarta. Seperti SMA Labschool, Tarki, SMP 19, dan SMP 29. Adapun ke-10 anak tersebut, dipilih oleh tim promosi GoGirl! berdasarkan intensitas membaca GoGirl! dan pengetahuan tentang GoGirl!.

Selain perubahan tampilan sampul, redesign juga dilakukan GoGirl! pada tampilan di dalam majalahnya. Dibandingkan majalah sebelumnya, tampilan di dalam majalah GoGirl! saat ini dibuat lebih minimalis, clean, dan artsy sesuai dengan konsep Playzine. Hal ini dapat dilihat dari pemanfaatan white spaces dan jenis font yang berbeda dari pengemasan sebelumnya. Selain itu, pengunaan foto pun semakin dikurangi GoGirl! agar dapat lebih menonjolkan sisi seni di dalam majalahnya.

Namun selain perubahan elemen tangible. Dalam penerapannya, proses rebranding juga dapat membuat perubahan pada elemen intangible-nya atau elemen brand yang tidak terlihat. Salah satunya adalah cara interaksi antara GoGirl! dan pembacanya. Dimana GoGirl! menyajikan sejumlah cara yang dapat meningkatkan intensitas interaksi antara GoGirl! dan pembacanya. Adapun cara-cara yang dimaksud dengan peneliti di sini adalah dengan adanya sejumlah konten kreatif dalam GoGirl! yang baru. Seperti Fill In The Blank yang dapat diisi oleh pembacanya, lalu Quotes Pages yang dapat difoto oleh pembacanya, dan Crafty Pages yang dapat dikreasikan oleh pembacanya. Hasil seluruh aktivitas itu, diwadahi GoGirl! melalui instagramnya @gogirlmagz dengan hashtag \#ggrep yang dapat diisi oleh pembacanya.

Selain itu elemen intangible GoGirl! yang berubah dalam rebranding GoGirl! ini adalah manajemen redaksi GoGirl!. Adapun yang dimaksud manajemen redaksi menurut Goerge R. Terry dan L.W. Rue adalah penerapan rangkaian kegiatan dari fungsi manajemen seperti Planning, Organizing, Actuating, dan Controling atau yang terkenal dengan istilah POAC.

Dimana fungsi planning atau perencanaan adalah tahap pemutusan tujuan yang akan dikejar selama jangka waktu yang akan datang dan apa yang akan dilakukan agar tujuan 
tercapai. Fungsi organizing atau pengorganisasian adalah tahap penentuan, pengelompokan, dan penyusunan macam-macam kegiatan untuk mencapai tujuan. Fungsi actuating atau penggerakan adalah tahap membangkitkan dan mendorong semua anggota supaya berkehendak dan berusaha dengan keras untuk mencapai tujuan yang serasi dengan perencanaan dan pengorganisasin dari pihak pimpinan. Fungsi controling atau pengawasan adalah tahap untuk mengetahui kondisi dari kegiatan yang sedang dilakukan, dengan tujuan untuk mengetahui sampai sejauh mana tingkat pencapaian dan penyelesaian kegiatan dalam memenuhi tujuan yang diharapkan.

Menurut Syarifah Sahnath, rebranding GoGirl! menjadi media hibrida Playzine tidak memberikan perubahan manajemen redaksi yang terlalu besar. Dari ke-empat fungsi manajemen redaksi yang disebutkan oleh Goerge R. Terry dan L.W. Rue di atas, implikasi rebranding GoGirl! menjadi media hibrida Playzine hanya terjadi pada fungsi perencanaan dan fungsi pengorganisasian.

Pada fungsi perencanaan, GoGirl! mengambil keputusan untuk merombak kembali seluruh konten di dalam majalahnya. Menurut Anita Moran, proses perombakan ini menitikberatkan pada relevansi konten GoGirl!. Baik itu relevansi antara konten GoGirl! yang lama dengan konsep GoGirl! yang baru maupun relevansi antara konten GoGirl! yang lama dengan dunia media sosial saat ini. Berikut hasil perombakan konten GoGirl!:

Tabel 1. Pertimbangan Dalam Penetapan Rubrik GoGirl! Setelah Rebranding

\begin{tabular}{|c|c|c|c|}
\hline No & Nama Rubrik & Penjelasan Rubrik & Keterangan \\
\hline 1. & Masshead & $\begin{array}{l}\text { Berisi tentang informasi } \\
\text { struktur editorial dalam } \\
\text { manajemen redaksi GoGirl!. } \\
\text { Beserta informasi tentang } \\
\text { budaya atau anggota GoGirl!. }\end{array}$ & $\begin{array}{l}\text { Rubrik ini sudah ada di majalah } \\
\text { sebelumnya dan dipertahankan } \\
\text { karena merupakan salah satu } \\
\text { bagian terpenting dalam sebuah } \\
\text { majalah }\end{array}$ \\
\hline 2. & Menu & $\begin{array}{l}\text { Berisi tentang penjelasan isi } \\
\text { majalah }\end{array}$ & $\begin{array}{l}\text { Rubrik ini sudah ada di majalah } \\
\text { sebelumnya dan dipertahankan } \\
\text { karena merupakan salah satu } \\
\text { bagian terpenting dalam sebuah } \\
\text { majalah }\end{array}$ \\
\hline 3. & Fill In The Blank & $\begin{array}{l}\text { Berisi halaman interaktif yang } \\
\text { mengajak pembaca untuk } \\
\text { menulis, menggambar, atau } \\
\text { mewarnai di majalah GoGirl!. }\end{array}$ & $\begin{array}{l}\text { Rubrik ini adalah rubrik baru yang } \\
\text { ditambahkan dalam majalah } \\
\text { GoGirl!. Rubrik ini ada karena } \\
\text { konsep baru GoGirl! sekarang yang } \\
\text { ingin pembaca tidak hanya sekedar } \\
\text { membaca tetapi juga dapat bermain } \\
\text { melalui halaman-halaman GoGirl!. } \\
\text { Dalam rubrik ini pembaca juga } \\
\text { dapat memotret dan mengunggah } \\
\text { hasil karyanya ke instagram dengan } \\
\text { hastag \#ggplay. Hasil karya terpilih } \\
\text { akan diunggah kembali oleh } \\
\text { GoGirl! melalui akun instagramnya } \\
\text { @gogirlmagz }\end{array}$ \\
\hline
\end{tabular}




\begin{tabular}{|c|c|c|c|}
\hline 4. & Quick Class & $\begin{array}{l}\text { Berisi rangkuman informasi } \\
\text { penting yang terjadi di bulan } \\
\text { sebelumnya }\end{array}$ & $\begin{array}{l}\text { Rubrik ini sudah ada di majalah } \\
\text { sebelumnya dan dipertahankan } \\
\text { karena masih dirasa penting untuk } \\
\text { remaja saat ini }\end{array}$ \\
\hline 5 & Recommendation & $\begin{array}{l}\text { Rubrik ini adalah gabungan } \\
\text { rekomendasi tentang film, } \\
\text { musik, tempat, dan makanan } \\
\text { atau minuman. }\end{array}$ & $\begin{array}{l}\text { Rubrik ini adalah gabungan dan } \\
\text { tambahan dari beberapa rubrik } \\
\text { yang ada dimajalah sebelumnya. } \\
\text { Alasan rubrik ini dipertahankan dan } \\
\text { ditambahkan adalah agar majalah } \\
\text { GoGirl! tetap update dengan tren } \\
\text { musik, film, tempat, dan makanan } \\
\text { atau minuman remaja saat ini }\end{array}$ \\
\hline 6. & Chill Places & $\begin{array}{l}\text { Berisi artikel mendalam } \\
\text { tentang sebuah tempat yang } \\
\text { sedang menjadi tren. }\end{array}$ & $\begin{array}{l}\text { Rubrik ini adalah rubrik baru yang } \\
\text { ditambahkan dalam majalah } \\
\text { GoGirl!. Rubrik ini ada karena } \\
\text { mengingat tingginya kebiasaan } \\
\text { nongkrong pada anak remaja saat } \\
\text { ini }\end{array}$ \\
\hline 7. & Mood & $\begin{array}{l}\text { Rubrik ini menggambarkan } \\
\text { feel pembuka dari keseluruhan } \\
\text { isi majalah. }\end{array}$ & $\begin{array}{l}\text { Rubrik ini adalah rubrik baru yang } \\
\text { ditambahkan dalam majalah } \\
\text { GoGirl!. Untuk pembuatannya, } \\
\text { rubrik ini dapat dibuat sendiri oleh } \\
\text { internal GoGirl! dan dapat pula } \\
\text { dibuat oleh pihak eksternal } \\
\text { GoGirl!. Keputusan pembuatan } \\
\text { rubrik ini tergantung dari ada } \\
\text { tidaknya kerja sama GoGirl! } \\
\text { dengan pihak eksternal. }\end{array}$ \\
\hline 8. & Cover Story & $\begin{array}{l}\text { Berisi artikel mendalam } \\
\text { tentang sampul }\end{array}$ & $\begin{array}{l}\text { Rubrik ini sudah ada dimajalah } \\
\text { sebelumnya. Namun penyajian } \\
\text { rubrik dan penentuan ada tidaknya } \\
\text { rubrik Cover Story ini berbeda } \\
\text { dengan ketentuan majalah } \\
\text { sebelumnya. Dalam hal penyajian, } \\
\text { rubrik Cover Story ini kadang } \\
\text { dikaitkan dengan web GoGirl! di } \\
\text { gogirlmagz.com. Adapun untuk } \\
\text { masalah penentuan ada tidaknya } \\
\text { rubrik Cover Story ini ditentukan } \\
\text { dari ada tidaknya kerja sama } \\
\text { GoGirl! dengan pihak eksternal } \\
\text { (brand, dll) untuk penyajian } \\
\text { sampul. }\end{array}$ \\
\hline
\end{tabular}


ISSN 2549-0559 (cetak) ISSN 2549-1946 (online)

Volume 02 Nomor 01 Tahun 2019

\begin{tabular}{|c|c|c|c|}
\hline 9. & Main Report & $\begin{array}{l}\text { Berisi artikel mendalam } \\
\text { tentang isu lifestyle }\end{array}$ & $\begin{array}{l}\text { Rubrik ini sudah ada di majalah } \\
\text { sebelumnya dan dipertahankan } \\
\text { karena merupakan salah satu } \\
\text { bagian terpenting dalam sebuah } \\
\text { majalah. Diawal rebranding } \\
\text { tepatnya bulan Oktober, GoGirl! } \\
\text { hanya menyediakan satu artikel } \\
\text { dalam rubrik Main Report. Namun } \\
\text { karena berbagai masukan yang } \\
\text { datang dari pembaca yang merasa } \\
\text { artikel GoGirl! yang baru lebih } \\
\text { sedikit. Akhirnya sejak bulan } \\
\text { Januari GoGirl! menyediakan tiga } \\
\text { artikel dalam rubrik Main Report. }\end{array}$ \\
\hline 10. & Spot Light On & $\begin{array}{l}\text { Berisi wawancara tanya jawab } \\
\text { dengan artis atau penyanyi } \\
\text { yang sedang tren }\end{array}$ & $\begin{array}{l}\text { Rubrik ini sudah ada di majalah } \\
\text { sebelumnya dan dipertahankan } \\
\text { karena masih relevan dengan dunia } \\
\text { media sosial saat ini. Namun } \\
\text { penyajian rubrik ini sedikit diubah } \\
\text { dari penyajian yang ada dalam } \\
\text { majalah sebelumnya. Dalam } \\
\text { GoGirl! yang baru, rubrik ini hanya } \\
\text { mencantumkan lima tanya jawab } \\
\text { dan untuk tanya jawab yang lebih } \\
\text { lengkapnya dikaitkan melalui web } \\
\text { GoGirl! di gogirlmagz.com }\end{array}$ \\
\hline 11. & Quote Page & $\begin{array}{l}\text { Berisi kutipan-kutipan yang } \\
\text { sesuai dengan topik GoGirl! } \\
\text { bulan tersebut }\end{array}$ & $\begin{array}{l}\text { Rubrik ini adalah rubrik baru yang } \\
\text { ditambahkan dalam majalah } \\
\text { GoGirl!. Rubrik ini ada untuk } \\
\text { meningkatkan interaksi dengan } \\
\text { pembaca. Dalam rubrik ini } \\
\text { pembaca juga dapat memotret dan } \\
\text { mengunggah hasil karyanya ke } \\
\text { instagram dengan hastag \#ggplay. } \\
\text { Hasil karya terpilih akan diunggah } \\
\text { kembali oleh GoGirl! melalui akun } \\
\text { instagram-nya@gogirlmagz }\end{array}$ \\
\hline 12. & Ask Us & $\begin{array}{l}\text { Rubrik ini berisi pertanyaan- } \\
\text { pertanyaan dari pembaca } \\
\text { GoGirl! }\end{array}$ & $\begin{array}{l}\text { Rubrik ini sudah ada di majalah } \\
\text { sebelumnya dan dipertahankan } \\
\text { karena mempertimbangkan } \\
\text { banyaknya pertanyaan dari } \\
\text { pembaca yang masuk ke email } \\
\text { GoGirl! setiap harinya }\end{array}$ \\
\hline 13. & Say What & $\begin{array}{l}\text { Rubrik ini berisi tentang } \\
\text { tanggapan pembaca GoGirl! } \\
\text { akan isu yang diberikan oleh } \\
\text { GoGirl! }\end{array}$ & $\begin{array}{l}\text { Rubrik ini adalah rubrik yang } \\
\text { ditambahkan dalam majalah } \\
\text { GoGirl! yang baru. Rubrik ini ada } \\
\text { untuk meningkatkan interaksi } \\
\text { dengan pembaca dan GoGirl! }\end{array}$ \\
\hline
\end{tabular}


Volume 02 Nomor 02 Tahun 2019

\begin{tabular}{|c|c|c|c|}
\hline 14. & $\begin{array}{l}\text { Feature Fun } \\
\text { Article }\end{array}$ & $\begin{array}{l}\text { Berisi artikel mendalam } \\
\text { tentang isu lifestyle }\end{array}$ & $\begin{array}{l}\text { Rubrik ini sudah ada di majalah } \\
\text { sebelumnya dan dipertahankan } \\
\text { karena merupakan salah satu } \\
\text { bagian terpenting dalam sebuah } \\
\text { majalah }\end{array}$ \\
\hline 15. & $\begin{array}{l}\text { Feature Carrier } \\
\text { Coach }\end{array}$ & $\begin{array}{l}\text { Berisi artikel mendalam } \\
\text { tentang profil seseorang yang } \\
\text { menginspirasi }\end{array}$ & $\begin{array}{l}\text { Rubrik ini sudah ada di majalah } \\
\text { sebelumnya dan sebenarnya sempat } \\
\text { dihilangkan di awal rebranding } \\
\text { GoGirl!. Namun karena berbagai } \\
\text { masukan yang datang dari pembaca } \\
\text { yang meminta GoGirl! memuat lagi } \\
\text { rubrik Feature Carrier Coach, } \\
\text { akhirnya sejak bulan Januari } \\
\text { GoGirl! mulai memuat kembali } \\
\text { rubrik Feature Carrier Coach ini }\end{array}$ \\
\hline 16. & $\begin{array}{l}\text { Feature } \\
\text { Personality }\end{array}$ & $\begin{array}{l}\text { Berisi artikel mendalam } \\
\text { tentang personality remaja } \\
\text { saat ini }\end{array}$ & $\begin{array}{l}\text { Rubrik ini sudah ada di majalah } \\
\text { sebelumnya dan dipertahankan } \\
\text { karena masih dirasa penting untuk } \\
\text { remaja saat ini }\end{array}$ \\
\hline 17. & Teenage Diary & $\begin{array}{l}\text { Rubrik ini berisi tentang } \\
\text { curhatan dari orang yang tidak } \\
\text { ingin disebut namanya }\end{array}$ & $\begin{array}{l}\text { Rubrik ini adalah rubrik baru yang } \\
\text { ditambahkan dalam majalah } \\
\text { GoGirl!. Rubrik ini ada untuk } \\
\text { memberikan ruang bagi pembaca } \\
\text { maupun orang lain yang ingin } \\
\text { berbicara tetapi bingung harus } \\
\text { berbicara kemana. Dalam rubrik } \\
\text { ini, curhatan bisa datang dari } \\
\text { pembaca GoGirl! tetapi bisa pula } \\
\text { datang dari narasumber yang telah } \\
\text { di cari oleh GoGirl! }\end{array}$ \\
\hline 18. & Feature Tips & $\begin{array}{l}\text { Rubrik ini berisi berbagai tips } \\
\text { seputar lifestyle }\end{array}$ & $\begin{array}{l}\text { Rubrik ini sudah ada di majalah } \\
\text { sebelumnya dan dipertahankan } \\
\text { karena masih relevan dengan dunia } \\
\text { media sosial saat ini }\end{array}$ \\
\hline 19. & Reader's Page & $\begin{array}{l}\text { Berisi informasi atau } \\
\text { rekomendasi yang datang dari } \\
\text { pembaca GoGirl! }\end{array}$ & $\begin{array}{l}\text { Rubrik ini sudah ada di majalah } \\
\text { sebelumnya, hanya saja di majalah } \\
\text { sebelumnya rubrik ini bernama } \\
\text { Post Anything. Rubrik ini diisi oleh } \\
\text { pembaca GoGirl! yang } \\
\text { memberikan informasi atau } \\
\text { rekomendasi sesuai dengan culture } \\
\text { GoGirl! }\end{array}$ \\
\hline 20. & It Girl & $\begin{array}{l}\text { Berisi tentang profil remaja } \\
\text { perempuan biasa (bukan dari } \\
\text { kalangan artis atau orang } \\
\text { terkenal lainnya) yang } \\
\text { menginspirasi }\end{array}$ & $\begin{array}{l}\text { Rubrik ini adalah rubrik baru yang } \\
\text { ditambahkan dalam majalah } \\
\text { GoGirl!. Rubrik ini ada untuk } \\
\text { memberikan cerita baru yang fresh } \\
\text { kepada pembaca GoGirl!. Namun } \\
\text { sejak bulan Januari, rubrik ini } \\
\text { dihilangkan dan diganti dengan } \\
\text { rubrik Feature Carier Coach }\end{array}$ \\
\hline
\end{tabular}


ISSN 2549-0559 (cetak) ISSN 2549-1946 (online)

Volume 02 Nomor 01 Tahun 2019

\begin{tabular}{|c|c|c|c|}
\hline 21. & Look We Love & $\begin{array}{l}\text { Berisi beberapa foto gaya } \\
\text { fashion pilihan GoGirl! }\end{array}$ & $\begin{array}{l}\text { Rubrik ini sudah ada di majalah } \\
\text { sebelumnya dan dipertahankan } \\
\text { karena merupakan salah satu } \\
\text { bagian terpenting dalam sebuah } \\
\text { majalah gaya hidup }\end{array}$ \\
\hline 22. & It Wear & $\begin{array}{l}\text { Berisi beberapa foto item } \\
\text { fashion pilihan GoGirl! }\end{array}$ & $\begin{array}{l}\text { Rubrik ini sudah ada di majalah } \\
\text { sebelumnya dan dipertahankan } \\
\text { karena merupakan salah satu } \\
\text { bagian terpenting dalam sebuah } \\
\text { majalah gaya hidup }\end{array}$ \\
\hline 23. & Crafty Page & $\begin{array}{l}\text { Rubrik ini berisi halaman } \\
\text { kreatif yang bisa dipotong atau } \\
\text { dikreasikan oleh pembaca } \\
\text { GoGirl! }\end{array}$ & $\begin{array}{l}\text { Rubrik ini adalah rubrik baru yang } \\
\text { ditambahkan dalam majalah } \\
\text { GoGirl!. Rubrik ini ada karena } \\
\text { konsep baru GoGirl! sekarang yang } \\
\text { ingin pembaca tidak hanya sekedar } \\
\text { membaca tetapi juga dapat bermain } \\
\text { melalui halaman-halaman GoGirl!. } \\
\text { Dalam rubrik ini pembaca juga } \\
\text { dapat memotret dan mengunggah } \\
\text { hasil karyanya ke instagram dengan } \\
\text { hastag \#ggplay. Hasil karya terpilih } \\
\text { akan diunggah kembali oleh } \\
\text { GoGirl! melalui akun instagramnya } \\
\text { @gogirlmagz }\end{array}$ \\
\hline 24. & Fashion Feature & $\begin{array}{l}\text { Berisi artikel mendalam } \\
\text { tentang isu fashion }\end{array}$ & $\begin{array}{l}\text { Rubrik ini adalah rubrik baru yang } \\
\text { ditambahkan dalam majalah } \\
\text { GoGirl!. Rubrik ini ada untuk } \\
\text { membahas lebih dalam tentang } \\
\text { fenomena yang terjadi dalam dunia } \\
\text { fashion saat ini. Seperti sejarahnya, } \\
\text { tren, dan lain-lain. }\end{array}$ \\
\hline 25. & Fashion Spread & $\begin{array}{l}\text { Berisi rangkaian hasil fashion } \\
\text { photoshoot yang dilakukan } \\
\text { GoGirl! }\end{array}$ & $\begin{array}{l}\text { Rubrik ini sudah ada di majalah } \\
\text { sebelumnya dan dipertahankan } \\
\text { karena merupakan salah satu } \\
\text { bagian terpenting dalam sebuah } \\
\text { majalah gaya hidup. Namun ada } \\
\text { yang berbeda dari pengemasan } \\
\text { rubrik Fashion Spread dalam } \\
\text { GoGirl! yang baru. Dimana dari } \\
\text { dua fashion photoshoot yang } \\
\text { dilakukan GoGirl! dikerjakan oleh } \\
\text { dua stylish yang berbeda. Satu } \\
\text { fashion photoshoot dikerjakan oleh } \\
\text { stylish GoGirl! dan fashion } \\
\text { photoshoot lainnya dikerjakan oleh } \\
\text { stylish kontibutor luar. Dengan } \\
\text { begitu feel yang dihasilkan dari } \\
\text { masing-masing fashion photoshoot } \\
\text { jauh berbeda. }\end{array}$ \\
\hline
\end{tabular}




\begin{tabular}{|c|c|c|c|}
\hline 26. & $\begin{array}{l}\text { Beauty Store } \\
\text { Seller }\end{array}$ & $\begin{array}{l}\text { Berisi informasi apa saja } \\
\text { produk kecantikan yang } \\
\text { sedang laku dipasaran }\end{array}$ & $\begin{array}{l}\text { Rubrik ini adalah rubrik baru yang } \\
\text { ditambahkan dalam majalah } \\
\text { GoGirl!. Rubrik ini ada untuk } \\
\text { memberikan informasi terbaru } \\
\text { seputar beauty kepada pembaca } \\
\text { dari hasil kurasi GoGirl! Di } \\
\text { beberapa toko kecantikan Indonesia }\end{array}$ \\
\hline 27. & Beauty Muse & $\begin{array}{l}\text { Berisi artikel mendalam } \\
\text { seputar kecantikan beauty } \\
\text { influencer }\end{array}$ & $\begin{array}{l}\text { Rubrik ini adalah rubrik baru yang } \\
\text { ditambahkan dalam majalah } \\
\text { GoGirl!. Rubrik ini ada untuk } \\
\text { memberikan informasi terbaru } \\
\text { seputar beauty kepada pembaca } \\
\text { dari hasil wawancara GoGirl! } \\
\text { dengan beauty influencer } \\
\end{array}$ \\
\hline 28. & Beauty Tips & $\begin{array}{l}\text { Rubrik ini berisi berbagai tips } \\
\text { seputar kecantikan }\end{array}$ & $\begin{array}{l}\text { Rubrik ini sudah ada di majalah } \\
\text { sebelumnya dan dipertahankan } \\
\text { karena merupakan salah satu } \\
\text { bagian terpenting dalam sebuah } \\
\text { majalah gaya hidup }\end{array}$ \\
\hline 29. & Try & $\begin{array}{l}\text { Berisi tentang review produk } \\
\text { yang dipilih dan dicoba } \\
\text { langsung oleh tim GoGirl!. }\end{array}$ & $\begin{array}{l}\text { Rubrik ini adalah rubrik baru yang } \\
\text { ditambahkan dalam majalah } \\
\text { GoGirl!. Rubrik ini ada untuk } \\
\text { memberikan referensi kepada } \\
\text { pembaca GoGirl! seputar } \\
\text { kecantikan. Di rubrik ini, tim } \\
\text { GoGirl! memberikan review secara } \\
\text { jujur terkait produk kecantikan } \\
\text { yang sudah dicoba dan } \\
\text { membahasnya apakah sesuai atau } \\
\text { tidak dengan janji dari produk } \\
\text { tersebut. Rubrik Try ini juga } \\
\text { dikaitkan dengan youtube GoGirl! } \\
\text { di gogirlmagztv sehingga pembaca } \\
\text { GoGirl! dapat langsung melihat } \\
\text { cara pengaplikasian dan reaksi } \\
\text { produk }\end{array}$ \\
\hline 30. & $\begin{array}{l}\text { Body Health and } \\
\text { Beauty }\end{array}$ & $\begin{array}{l}\text { Berisi artikel mendalam } \\
\text { tentang isu kesehatan dan } \\
\text { kecantikan badan }\end{array}$ & $\begin{array}{l}\text { Rubrik ini sudah ada di majalah } \\
\text { sebelumnya dan dipertahankan } \\
\text { karena masih dianggap penting } \\
\text { untuk remaja saat ini }\end{array}$ \\
\hline 31. & Jalan-jalan & $\begin{array}{l}\text { Berisi tentang kumpulan foto } \\
\text { lokasi yang dikirimkan oleh } 12 \\
\text { orang pembaca }\end{array}$ & $\begin{array}{l}\text { Rubrik ini sudah ada di majalah } \\
\text { sebelumnya dan dipertahankan } \\
\text { karena merupakan salah satu } \\
\text { bagian terpenting dalam sebuah } \\
\text { majalah gaya hidup. Namun ada } \\
\text { yang berbeda dari pengemasan } \\
\text { rubrik Jalan-jalan dalam GoGirl! } \\
\text { yang baru. Dimana pengemasannya } \\
\text { bukan lagi berupa artikel seperti }\end{array}$ \\
\hline
\end{tabular}


ISSN 2549-0559 (cetak) ISSN 2549-1946 (online)

Volume 02 Nomor 01 Tahun 2019

\begin{tabular}{|c|c|c|c|}
\hline & & & $\begin{array}{l}\text { majalah sebelumnya tetapi menjadi } \\
\text { kumpulan foto }\end{array}$ \\
\hline 32. & Hollywood Hype & $\begin{array}{l}\text { Berisi artikel mendalam } \\
\text { tentang isu dari dunia } \\
\text { hollywood }\end{array}$ & $\begin{array}{l}\text { Rubrik ini sudah ada di majalah } \\
\text { sebelumnya dan dipertahankan } \\
\text { karena ketertarikan GoGirl! pada } \\
\text { dunia hollywood. Hal itu dapat } \\
\text { terlihat dari tampilan sampul dan } \\
\text { artikel di majalah GoGirl! } \\
\text { sebelumnya. Oleh karena itu, } \\
\text { GoGirl! tidak ingin kehilangan ciri } \\
\text { khas itu dengan memberikan ruang } \\
\text { untuk isu dari dunia hollywood } \\
\text { melalui rubrik Hollywood Hype }\end{array}$ \\
\hline 33. & $\begin{array}{l}\text { Blogger } \\
\text { Colomnist }\end{array}$ & $\begin{array}{l}\text { Berisi artikel opini mendalam } \\
\text { dari seorang kolomnis atas isu } \\
\text { yang diberikan oleh GoGirl! }\end{array}$ & $\begin{array}{l}\text { Rubrik ini sudah ada di majalah } \\
\text { sebelumnya dan dipertahankan } \\
\text { karena masih dianggap penting. } \\
\text { Namun ada yang berbeda dari cara } \\
\text { pemilihan kolumnis dalam GoGirl! } \\
\text { yang baru. Dimana kolumnis } \\
\text { GoGirl! akan diganti setiap enam } \\
\text { bulan sekali agar opini yang } \\
\text { diberikan selalu fresh }\end{array}$ \\
\hline 34. & $\begin{array}{l}\text { Comic and } \\
\text { Ilustrator }\end{array}$ & $\begin{array}{l}\text { Rubrik ini berisi sindirian atas } \\
\text { tren yang terjadi saat ini. Baik } \\
\text { berupa komik maupun berupa } \\
\text { ilustrasi }\end{array}$ & $\begin{array}{l}\text { Rubrik ini adalah rubrik baru yang } \\
\text { ditambahkan dalam majalah } \\
\text { GoGirl!. Rubrik ini ada untuk } \\
\text { meningkatkan interaksi antara } \\
\text { pembaca dan GoGirl! }\end{array}$ \\
\hline 35. & Mail & Berisi surat pembaca GoGirl! & $\begin{array}{l}\text { Rubrik ini sudah ada di majalah } \\
\text { sebelumnya dan dipertahankan } \\
\text { karena mempertimbangkan } \\
\text { banyaknya pertanyaan dari } \\
\text { pembaca yang masuk ke email } \\
\text { GoGirl! setiap harinya }\end{array}$ \\
\hline 36. & Directory & $\begin{array}{l}\text { Berisi informasi seluruh } \\
\text { kontak produk yang ada di } \\
\text { majalah }\end{array}$ & $\begin{array}{l}\text { Rubrik ini sudah ada di majalah } \\
\text { sebelumnya dan dipertahankan } \\
\text { karena merupakan salah satu } \\
\text { bagian terpenting dalam sebuah } \\
\text { majalah }\end{array}$ \\
\hline 37. & Final Talk & $\begin{array}{l}\text { Rubrik ini berisi kesimpulan } \\
\text { dari keseluruhan isi majalah } \\
\text { yang disampaikan oleh } \\
\text { pemimpin redaksi GoGirl! }\end{array}$ & $\begin{array}{l}\text { Rubrik ini adalah rubrik yang } \\
\text { ditambahkan dalam majalah } \\
\text { GoGirl! yang baru. Rubrik ini ada } \\
\text { untuk meningkatkan interaksi } \\
\text { antara pembaca pemimpin redaksi } \\
\text { GoGirl! }\end{array}$ \\
\hline
\end{tabular}

Sumber: Hasil Penelitian 2017

Berdasarkan tabel di atas, dapat dilihat bahwa setelah rebranding menjadi media hibrida Playzine, GoGirl! tidak hanya menyajikan sejumlah konten artikel dan konten iklan tetapi juga sejumlah konten kreatif. Syarifah Sahnath mengatakan perubahan konten tersebut memperluas 
target khalayak GoGirl! ke dalam tiga karakter yaitu, karakter khalayak yang senang membaca, karakter khalayak yang senang berkreasi, dan karakter khalayak yang senang membaca dan senang berkreasi.

Selain itu, pada fungsi perencanaan juga terjadi perubahan alur kerja redaksi yang meliputi penambahan jumlah rapat bulanan dan jadwal kerja wartawan. Sebelum rebranding, dalam sebulan manajemen redaksi GoGirl! hanya memiliki dua rapat rutin memproduksi konten yaitu pra-editorial meeting dan ediorial meeting. Namun setelah rebranding, GoGirl! menambahkan dua rapat baru dalam manajemen redaksi GoGirl!. Kedua rapat tersebut yaitu rapat "art meeting" dan "video execution weekly meeting". Adapun untuk jadwal kerja wartawan, GoGirl! menerapkan kebijakan baru dengan ritme kerja dua minggu untuk pengerjaan konten majalah, satu minggu untuk pengerjaan konten web, dan satu minggu lagi untuk pengerjaan konten video.

Pada fungsi pengorganisasian, perubahan terjadi pada penambahan beban kerja wartawan yang semakin banyak. Hal ini disebabkan karena adanya keinginan GoGirl! untuk memanfaatan dan meningkatan performa dari seluruh platform media yang dimiliki setelah rebranding. Anita Moran mengatakan jika dulu anggota redaksi GoGirl! bisa fokus menulis hanya pada majalah. Namun sekarang anggota redaksi GoGirl! juga harus membagi fokus menulis ke web dan media sosial. Adapun perbandingan tulisannya yaitu 5-6 artikel majalah dan 8 artikel web.

\section{a. Tahap Relaunching}

Proses relaunching menjadi proses terakhir dalam rebranding GoGirl!. Muzzelec (2004:35) menjelaskan tahap relaunching adalah tahap akhir dan penentuan bagaimana pelanggan, pesaing, dan pemangku kepentingan lain menganggap nama baru perusahaan. Adapun cara relaunching biasanya ditafsirkan berbeda-beda oleh sejumlah pihak dan perusahaan. Ada yang memanfaatkan publikasi secara cetak seperti brosur maupun pamflet tetapi ada pula yang melalui acara seperti press conference maupun gathering.

Dari hasil observasi peneliti, proses relaunching GoGirl! tidak dipublikasikan secara cetak atau acara seperti yang dijelaskan di atas. Proses relaunching GoGirl! dipublikasikan melalui akun instagram mereka @gogirlmagz pada tanggal 3 Oktober 2016. Dimana melalui cara tersebut GoGirl! tidak lagi memperkenalkan diri sebagai sebuah media konvensional majalah atau magazine melainkan sebuah media hybrid bernama Playzine. Dari publikasi tersebut, GoGirl! mendapat 1.599 likes dan 94 comments dari para pengikut instragramnya.

Awalnya Anita Moran, Nina Moran, dan Githa Moran memproyeksikan rencana relaunching terjadi di bulan Juli 2016. Namun karena kurang matangnya konsep baru GoGirl! dan kesiapan seluruh tim, akhirnya rencana relaunching diundur dan diganti menjadi bulan Oktober 2016.

Pengunduran waktu relaunching ini dianggap sebagai keputusan yang tepat bagi Syarifah Sahnath. Sebagai edior yang bertanggung jawab akan kualitas konten, Syarifah Sahnath mengakui bahwa keputusan relaunching di bulan Juli 2016 dinilai terlalu mendesak.

Muzellec dan Lambkin (2004:805) dalam artikel ilmiahnya yang berjudul Corporate Rebranding: Destroying, Transferring, or Cerating Brand Equity? menggambarkan rebranding menurut tingkat perubahan di dalam estetika marketing dan posisi brand. Dalam 
model ini, rebranding evolusioner digambarkan sebagai sebuah perkembangan kecil dalam posisi dan estetika perusahaan yang bersifat bertahap sehingga hampir tidak terlihat oleh pengamat luar. Adapun sebaliknya rebranding revolusioner digambarkan sebagai sebuah perubahan besar dalam posisi dan estetika yang secara mendasar biasanya dilambangkan dengan perubahan nama.

Dalam penelitian ini, rebranding GoGirl! menjadi media hibrida Playzine akan peneliti masukan ke dalam tingkat rebranding revolusioner. Mengingat hasil dari keseluruhan proses rebranding yang telah peneliti jelaskan di atas, GoGirl! telah melakukan beberapa perubahan yang cukup signifikan dari seluruh elemen GoGirl!. Selain itu, proses rebranding GoGirl! pun terbilang cukup cepat karena berlangsung selama enam bulan.

\section{Simpulan}

Berdasarkan hasil penelitian, alasan GoGirl! melakukan rebranding menjadi media hibrida Playzine disebabkan karena adanya kehadiran media online ditengah-tengah bisnis media cetak. Selain itu, dalam kurun waktu tiga tahun kebelakang GoGirl! jumlah oplah GoGirl! menurun dari 130.000 eksemplar menjadi 50.000 eksemplar. Hal ini dilihat sebagai dampak adanya perubahan pola bermedia target pembacanya yang berusia 15-25 tahun. Dimana saat ini, rentang usia tersebut dikenal sebagai generasi millenial atau digital native. Oleh karena itu, GoGirl! merasa perlu melakukan perubahan dengan menciptakan konsep media hibrida Playzine. Playzine ialah gabungan antara kata play yang berarti bermain dan zine dari kata magazine yang berarti majalah. Dengan rebranding menjadi media hibrida Playzine, GoGirl! ingin menjadi majalah yang tidak hanya mengajak pembaca sekedar membaca tetapi juga beraktivitas atau bermain.

Rebranding GoGirl! memuat empat tahap proses rebranding yaitu repositioning, renaming, redesign, dan relaunching. Pada tahap repositioning, GoGirl! mengubah tagline dari "Magazine For Real" dan menjadi "Inspired To Be Impactful" dan bentuk media GoGirl! yang bukan lagi diperkenalkan sebagai magazine atau majalah melainkan sebagai media hibrida. Tahap renaming, GoGirl! tidak lagi memperkenalkan diri sebagai magazine atau majalah melainkan Playzine. Adapun Playzine merupakan gabungan antara kata play yang berarti bermain dan zine dari kata magazine yang berarti majalah. Tahap redesign, GoGirl! mengubah sejumlah elemen tangible dan intangible. Tahap relaunching, GoGirl! memanfaatkan akun media sosial instagram mereka pada@gogirlmagz. Hal ini terbilang cukup efektif untuk menarik perhatian pembaca GoGirl! yang saat ini lebih dekat dengan dunia media sosial.

Rebranding GoGirl! menjadi media hibrida Playzine berimplikasi pada fungsi perencanaan dan pengorganisasian dalam manajemen redaksi GoGirl!. Dimana pada fungsi perencanaan, perubahan terjadi dalam penentuan konten GoGirl! yang tidak hanya menyajikan sejumlah konten artikel dan konten iklan tetapi juga sejumlah konten kreatif. Selain itu, pada fungsi perencanaan juga terjadi perubahan alur kerja redaksi yang meliputi penambahan jumlah rapat bulanan dan jadwal kerja wartawan. Adapun pada fungsi pengorganisasian, perubahan terjadi pada penambahan beban kerja wartawan yang semakin banyak. 
244 | Kajian Jurnalisme

ISSN 2549-0559 (cetak) ISSN 2549-1946 (online)

Volume 02 Nomor 02 Tahun 2019

\section{Daftar Pustaka}

Ardianto, Elvinaro. Lukiati Komala dan Siti Karlinah. (2014). Komunikasi Massa: Suatu Pengantar Edisi Revisi.

Baran, Stanley J. (2011). Pengantar Komunikasi Massa: Melek Media \& Budaya. Jakarta: Salemba Humanika. Bandung : Simbiosa Rekatama Media.

Considine, David. Julie Horton and Gary Moorman.(2009) Teaching and Reading Millenial Generation through Media Literacy. Journal Of Adolescent \& Adult Literacy Vo. 52, No. 6 pp. 471-481.

Djuroto, Totok. (2004). Manajemen Penerbitan Pers. Bandung: Remaja Rosdakarya.

Irawan, Hadi. (2004). Smarter Marketing Moves: Membangun Keunggulan Melalui Informasi, Komunikasi dan Produk. Jakarta: PT Elex Media Komputindo.

K. Yin, Robert. (2013). Studi Kasus, Desain dan Metode. Jakarta: PT Raja Grafindo Persada.

Kasali, Rhenald. (2005). Manajemen Public Relations Konsep dan Aplikasinya di Indonesia. Jakarta: PT. Pustaka Utama.

Leeuwis, Cees. (2013). Komunikasi Untuk Inovasi Pedesaan: Berpikir Kembali Tentang Penyuluhan Pertanian. Yogyakarta: Kanisius.

Laurent Muzellec, dkk. (2004). Corporate Rebranding an Axploratory Review. Irish Marketing Review. Supadiyanto. (2013). Implikasi Teknologi Digital dan Internet (Paperless Newspaper). DPPM UII (hal. 687-696). Yogyakarta: Universitas Islam Indonesia.

Taufiqrokhman. (2016). Manajemen Strategik. Jakarta: Fakultas Ilmu Sosial dan Ilmu Politik Universitas Prof. Dr. Moestopo Beragama

Terry, J. George dan Leslie W. Rue. (2003). Dasar-Dasar Manajemen. Jakarta: Bumi Aksara.

Tjiptono, Fandy. (2008). Strategi Pemasaran. Edisi tiga. Jakarta: Andi, Alma, B 2007.Kewirausahaan. Bandung:Alfabeta.

Wirayawan, B. Mendiola. (2008). Kamus Brand A-Z, Jakarta: Red \& White Publishing.

\section{Website}

Kamus Besar Bahasa Indonesia Online

https://gogirlmagz.com

https://apjii.or.id/survei2017/download/NGCz4d0ReTmOlHXKfYSxjkgQvnJobr

http://jurnal.unpad.ac.id/kajian-jurnalisme 